Pego 1 of 2 Proj.

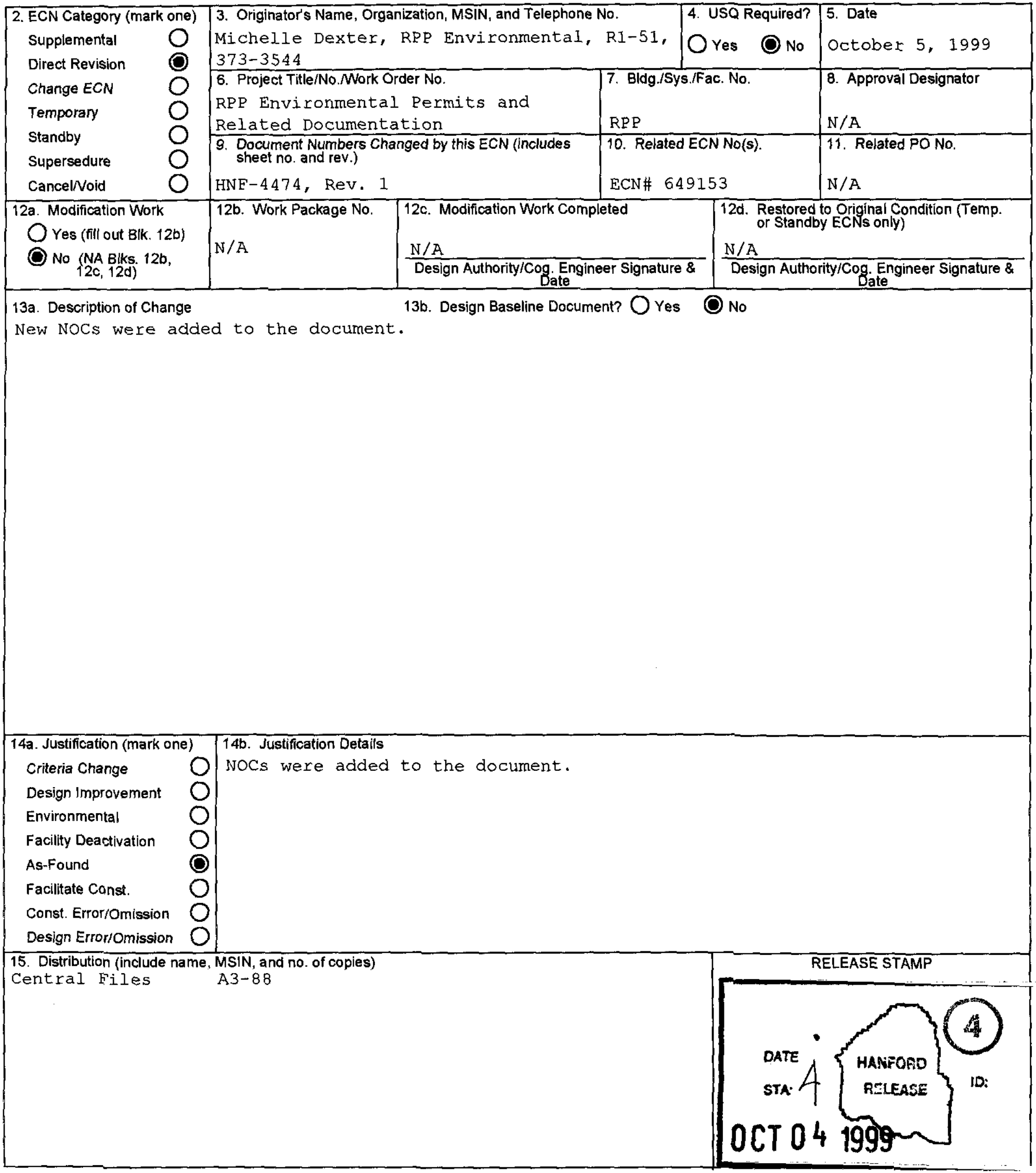




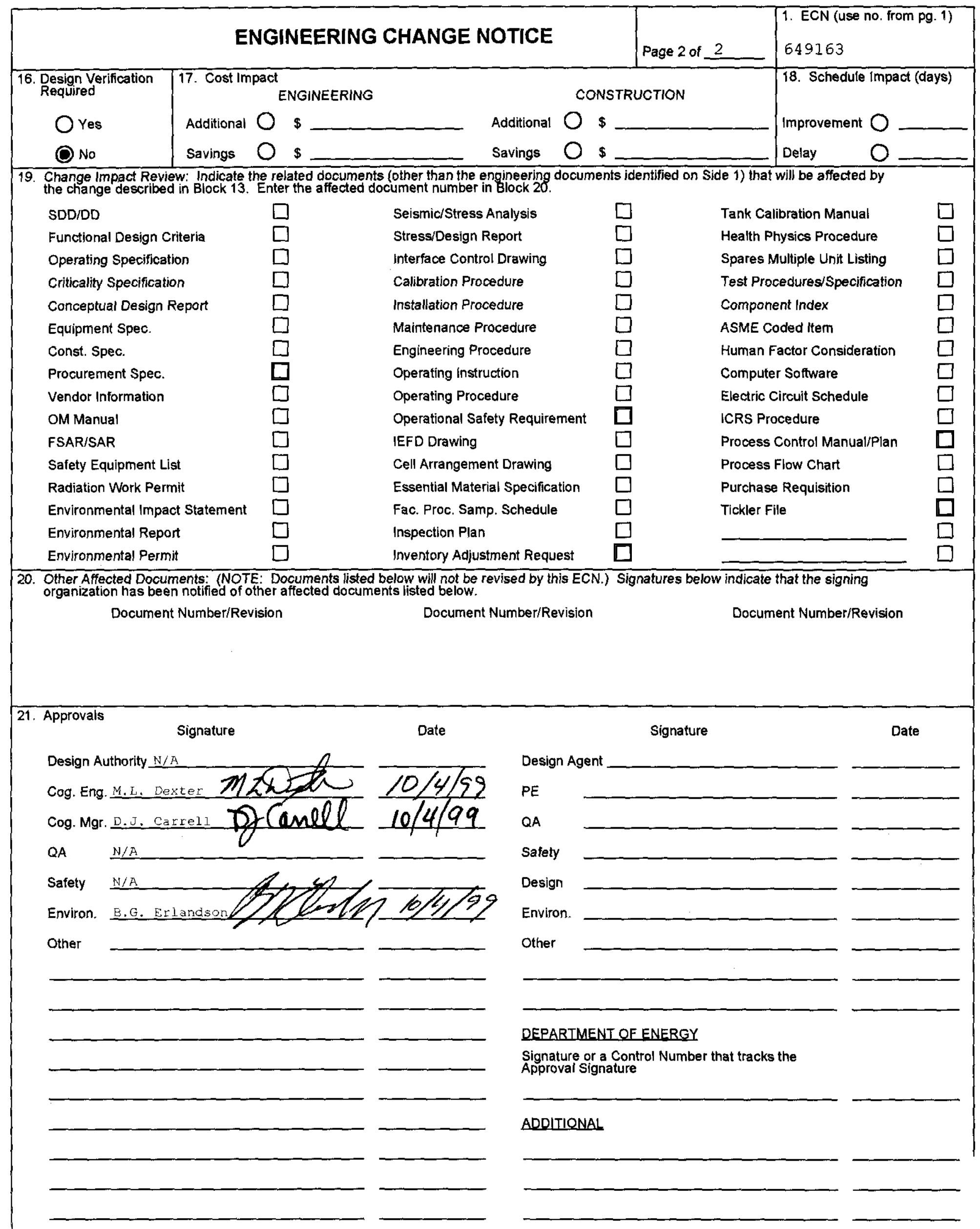




\title{
RPP ENVIRONMENTAL PERMITS AND RELATED DOCUMENTATION
}

\author{
Michelle Dexter \\ Lockheed Mart in Hanford Corporation, Richland, WA 99352 \\ U.S. Department of Energy Contract DE-AC06-99RL14047
}

$\begin{array}{lll}\text { EDT/ECN: } & 649163 & \text { UC: } 2030 \\ \text { Org Code: } & 7 \text { B200 } & \text { Charge Code: } 101785 / \text { CA30 } \\ \text { B\&R Code: } & \text { EW3120071 } & \text { Total Pages: } 36\end{array}$

Key Words: Permits, Notices of Correction, Notices of Violation, RCRA

Abstract: This document contains the current list of environmental permits and related documentation for TWRS facilities and activities.

TRADEMARK DISCLAIMER. Reference herein to any specific commercial product, process, or service by trade name, trademark, manufacturer, or otherwise, does not necessarily constitute or imply its endorsement, recommendation, or favoring by the United States Government or any agency thereof or $i$ ts contractors or subcontractors.

Printed in the United States of America. To obtain copies of this document, contact: Document Control services, P.O. Box 950, Mailstop H6-08, Richland WA 99352, Phone (509) 372-2420;

Fax (509) 376-4989.
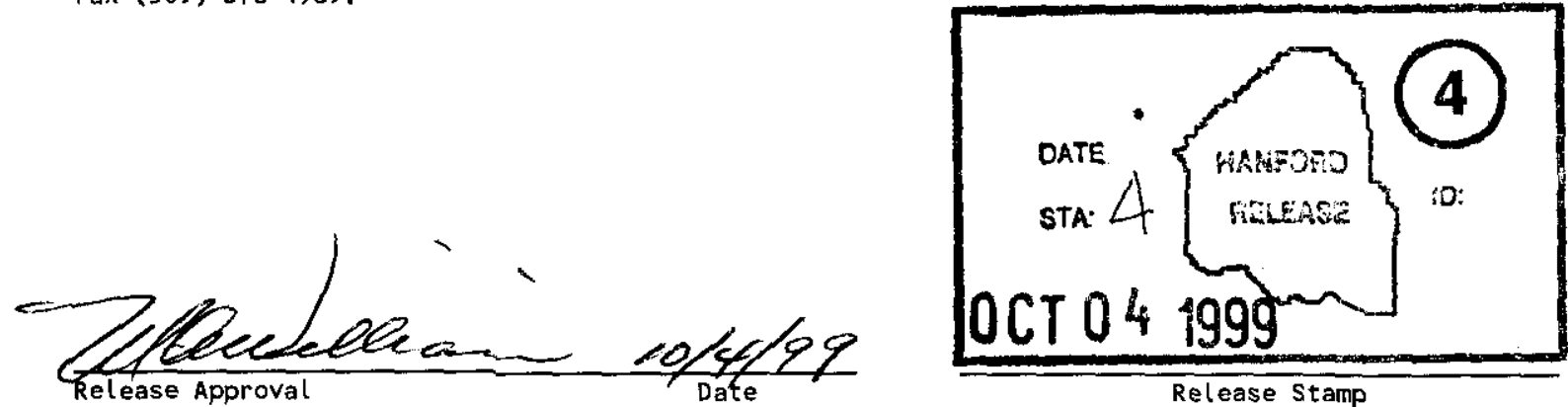

\section{Approved for Public Release}




\section{RECORD OF REVISION}

(1) Document Number

HNF-4474

Page 1

(2) Title

RPP Environmental Permits and Related Documentation

CHANGE CONTROL RECORD

\begin{tabular}{|c|c|c|c|c|}
\hline \multirow{2}{*}{ (3) } & \multirow{2}{*}{ Revision } & \multirow{2}{*}{ (4) Description of Change - Replace, Add, and Delete Pages } & \multicolumn{2}{|c|}{ Authorized for Release } \\
\hline & & & (5) Cog. Engr. & (6) Cog. Mgr. \\
\hline & 0 & (7) EDT-626594 5/11/99 & ML Dexter & DJ Carrell \\
\hline & 1 & Replace All Pages Per ECN-649153 8/02/99 & MI. Dexter A & DJ Carrell o00 \\
\hline RS & 2 & Replace A11 Pages Per ECN-649163 10/5/99 & ML Dexter $10 / 4$ & do Carrell $10 / 4 \sqrt{99}$ \\
\hline & & & & \\
\hline & & & & \\
\hline & & & & \\
\hline & & & & \\
\hline & & & & \\
\hline & & & & \\
\hline & & & & \\
\hline & & & & \\
\hline & & & & \\
\hline & & & & \\
\hline & & & & \\
\hline & & & & \\
\hline & & & & \\
\hline & & & & \\
\hline & & & & \\
\hline & & & & \\
\hline & & & & \\
\hline & & & & \\
\hline & & & & \\
\hline & & & & \\
\hline & & & & \\
\hline & & & & \\
\hline & & & & \\
\hline & & & & \\
\hline
\end{tabular}




\section{LEGAL DISCLAIMER}

This report was prepared as an account of work sponsored by an agency of the United States Government. Neither the United States Government nor any agency thereof, nor any of their employees, nor any of their contractors, subcontractors or their employees, makes any warranty, express or implied, or assumes any legal liability or responsibility for the accuracy, completeness, or any third party's use or the results of such use of any information, apparatus, product, or process disclosed, or represents that its use would not infringe privately owned rights. Reference herein to any specific commercial product, process, or service by trade name, trademark, manufacturer, or otherwise, does not necessarily constitute or imply its endorsement, recommendation, or favoring by the United States Government or any agency thereof or its contractors or subcontractors. The views and opinions of authors expressed herein do not necessarily state or reflect those of the United States Government or any agency thereof.

This report has been reproduced from the best available copy.

Printed in the United States of America

DISCLM-2.CHP (1-91) 


\title{
RPP Environmental Permits and Related Documentation
}

\author{
M. L. Dexter
}

Lockheed Martin Hanford Corp.

Date Published

October 1999

Prepared for the U.S. Department of Energy

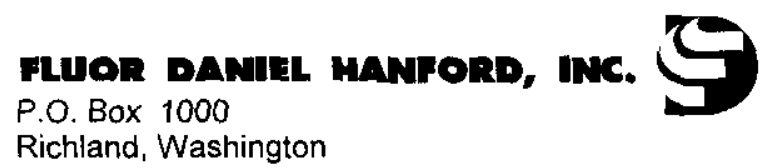

Richland, Washington

Hanford Management and Integration Contractor for the

U.S. Department of Energy under Contract DE-AC06-96RL13200 
HNF-4474, Rev. 2

RPP ENVIRONMENTAL PERMITS AND RELATED DOCUMENTATION 
HNF-4474, Rev. 2

RPP ENVIRONMENTAL PERMITS AND RELATED DOCUMENTATION

\section{Purpose and Scope}

This document contains the current list of environmental permits and related documentation for RPP facilities and activities. Copies of these permits and related approvals are maintained by RPP Environmental.

In addition, Notices of Correction and Notices of Violation are issued by State and Federal Regulators which are tracked by RPP Environmental to resolve any recently identified deficiencies. A listing of these recent Notices is provided as an attachment to this documents. These permits, approval conditions, and recent regulatory agency notices, constitute an important element of the RPP Authorization Envelope.

Permits are issued frequently and the reader is advised to check with RPP environmental for new permits or approval conditions. Interpretation of permit or approval conditions should be coordinated with RPP Environmental.

This document will be updated on a quarterly basis (with the first update scheduled to be issued in October of 1999). 
HNF-4474, Rev. 2

I. $\quad \underline{A I R}$

A. Routine Activities List Superseded on April 1999 by HNF-4327, Rev. 0

B. $\quad$ Site Wide Air Permits

1. RPP Portions of Site Wide Permit, F-001 Stack Registrations, enclosure to DOE-RL letter (R. Holt) number 93-RPS-243, to WDOH (A. Conklin), dated July 28, 1993.

a. NESHAPS Reassessment of Potential Radionuclide Emissions from the 296-S-15 Stack, letter from WHC (Dixon), number 9301990B R60, to DOE-RL (J. Rasmussen), dated August 27, 1996

b. NESHAPS FFCA Reassessment of Potential Radionuclide Emissions from the 296-S-15 Stack, letter from DOE-RL (J. Rasmussen), number 96-EAP-356, to WDOH (A. Conklin) and EPA (J. Leitch), dated September 16, 1996

2. Approved Hanford Site Air Operating Permit (When Issued)

C. Notices of Construction and Approvals, Operations

NOTE: Control of Airborne Radioactive Emissions for Frequently Performed TWRS Work Activities (ALARACT Demonstrations), HNF-4327, Rev. 0

\section{a. 241-A Tank Farm Guzzler (Short Form)}

"Short Form Radioactive Air Emissions Notice of Construction (NOC) for Guzzler Excavation and Backfilling Activities in Support of the 200 East Area A Farm Complex," Enclosure to DOE-RL letter ( $\mathrm{J}$. Rasmussen), number 98-EAP-037, to EPA ( $\mathrm{J}$. Leitch), dated January 30, 1998

Approval: WDOH Approval Sheet (A. Conkl in by P.J. Marte11), dated December 23, 1997

Approval: EPA letter (A. Frankel) to DOE-RL (J. Rasmussen), dated March 11, 1998 
b. 241-A-101 - Ventilation System - Portable Exhauster (Saltwell Pumping) - Non-Radioactive (Canceled $1 / 7 / 99)$

"Non-Radioactive Air Emissions Notice of Construction (NOC), Use of a Portable Exhauster on 241-A-101 Tank During

Saltwell Pumping and 0ther Routine Activities," DOE/RL-9628, March 1996, Enclosure to DOE-RL letter (J. Rasmussen), number 96-MSD-074, to Ecology (J. Stohr), dated May 2, 1996

Approval: Ecology letter (J. Stohr) to DOE-RL (J. Rasmussen), dated June 24, 1996

Notification of Start-Up: DOE-RL letter (J. Rasmussen), number 96-EAP-393, to Ecology (M. Szyszkowski), dated September 26, 1996

Approval to Start-Up:

Ecology letter (J. Stohr) to DOE-RL (J. Rasmussen), dated October 14, 1996

c. 241-A-101 - Ventilation System - Portable Exhauster (Saltwel1 Pumping) - Radioactive (Canceled 1/7/99)

"Radioactive Air Emissions Notice of Construction Use of a Portable Exhauster on 241-A-101 Tank During Saltwe11 Pumping and Other Routine Activities," DOE/RL-96-24, dated March 1996, Enclosure to D0E-RL letter ( $\mathrm{J}$. Rasmussen), number 96MSD-076, to WDOH (A. Conklin) and EPA (J. Leitch), dated May 2,1996

Approva 1: WDOH letter (A. Conkl in), number AIR-96-607, to DOE-RL (J. Rasmussen), dated June 17, 1996

Approva1: EPA letter (A. Franke1), to DOE-RL ( $J$. Rasmussen), dated July 2, 1996

Notification to Start-Up: DOE-RL letter (J. Rasmussen), number 96-EAP-392, to EPA ( $\mathrm{J}$. Leitch), dated September 26, 1996 
HNF-4474, Rev. 2

\section{d. 241-AN Exhauster Fans (Field Work is On-Hold)}

"Notice of Construction for Upgrading the 241-AN Primary System Fans and Heaters, "Enclosure to DOE-RL letter (J. Rasmussen), number 98-EAP-021, to WDOH (A. Conkl in) and EPA (J. Leitch), dated April 27, 1998

Approva1: WDOH letter (A. Conk7 in), number AIR-98-614, to DOE-RL (J. Rasmussen), dated June 30, 1998

e. 241-AN-107 Mixer Pump Installation

Approval: WDOH Routine Technical Assistance Meeting Minutes, Installation of Mixer Pump within 107AN UST, Page 5 of 7, June 8, 1994

f. 241-AN-107 Caustic Addition

Approval: WDOH Routine Technical Assistance Meeting Minutes, Addition of Caustic to Tank 107-AN and Install Mixer Pump, Page 3 and 4 of 7, April 14, 1994

g. 241-AP-102 and 241-AP-104 - Radioactive (Not Yet Submitted to Regulators)

"Radioactive Air Emissions Notice of Construction for Installation and Operation of an Initial Tank Retrieval System in Tanks 241-AP-102 and 241-AP-104, Project W-211," Enclosure to FDH letter (A. Umek), number FDH-9852527, to DOE-RL (J. Peschong), dated Apri1 13, 1998

h. 241-AY and 241-AZ - Ventilation Upgrades - (Project W-151 \& Project W-030) - Non-Radioactive

"Notice of Construction Application Pursuant to Washington Administrative Code 173-460 for Ventilation Upgrades, 241-AY and 241-AZ Tank Farms," Enclosure to DOE-RL letter ( $\mathrm{J}$. Bauer), number 94-RPS-148, to Ecology (J. Stohr), dated March 2, 1994

"Response to Request for Additional Information - 241-AY and 241-AZ Tank Farms Ventilation Upgrades," Enclosure to DOE-RL letter ( $S$. Wisness), number 94-RPS-276, to Ecology (D. Lundstrom and J. Stohr), dated June 30, 1994

Approval: Ecology letter (J. Stohr) to DOE-RL (S. Wisness), dated August 29, 1994 
"Revision to Notice of Construction (NOC) Permit 94-07 for Project W-15I Mixer Pump Testing in Tank 241-AZ-101, "DOE-RL letter 97-EAP-574 (J. Rasmussen) to Ecology (M. Wilson), dated August 25, 1997

Approval: Ecology letter (M. Wilson) to DOE-RL (J. Rasmussen), dated December 22, 1997

Notification of Start-Up: DOE-RL letter (J. Rasmussen) number 98-EAP-128, to Ecology (M. Wilson), dated March 3, 1998

"New Source Review Exemption Request for Approval on the Operation of AY/AZ Tank Farm Exhauster Stack 296-A-42 at 0.5 Cubic Meters Per Second", D0E-RL letter 98-EAP-450 ( $\mathrm{J}$. Rasmussen) to Ecology (M. Wilson), dated August 22, 1998

Approval: Ecology letter (M. Wilson) to DOE-RL ( $\mathrm{J}$. Rasmussen), dated September 1, 1998

i. 241-AY and 241-AZ - Ventilation Upgrades - (Project W-151 \& Project W-030) - Radioactive

"Radioactive Air Emissions Program, Notice of Construction, Ventilation Upgrades, 241-AY and 241-AZ Tank Farms,"

Enclosure to DOE-RL letter (J. Bauer), number 94-RPS-150, to WDOH (A. Conklin), dated March 2, 1994

Approval: WDOH letter (A. Conklin), number AIR-94-502, to DOE-RL (S. Wisness), May 5, 1994

"Radioactive Air Emissions Program, Notice of Construction, Ventilation Upgrades, 241-AY and 241-AZ Tank Farms,"

Enclosure to DOE-RL letter (J. Bauer), number 94-RPS-149, to EPA (J. McCormick), dated March 2, 1994

Approval: EPA letter (J. McCormick) to DOE-RL (J. Bauer), dated March 15, 1994

"Modification of Approval to Construct Monitoring Requirements for 241-AY and 241-AZ Tank Farm Ventilation Upgrades (Project $W-030$ ) and Mixer Pump Installation and Operation (Project $W-151$ ), Enclosure to DOE-RL letter ( $J$. Rasmussen), number 96-MSD-090, to WDOH (A. ConkTin), dated June 10, 1996

Approva1: WDOH letter (A. Conk1 in), number AIR-96-702, to DOE-RL (J. Rasmussen), dated July 10, 1996 
HNF-4474, Rev. 2

"Modification of Approval to Construct Monitoring Requirements for 241-AY and 241-AZ Tank Farm Ventilation Upgrades (Project $W-030$ ) and Mixer Pump Installation and Operation (Project W-151), "Enclosure to DOE-RL letter (J. Rasmussen), number 96-MSD-091, to EPA (J. Leitch), dated June 10,1996

Approval: EPA letter (A. Frankel) to DOE-RL ( $J$. Rasmussen), dated September 3, 1996

"Clarifications Pursuant to Activities Associated with Project W-030," Enclosure to D0E-RL letter (J. Rasmussen), number 97-EAP-529, to WDOH (A. Conklin), dated June 27, 1997

Approval: WDOH Telephone Conference Memorandum with John Bates and Hector Rodriguez, dated July 8, 1997

"Radioactive Air Emissions Notice of Construction for Ventilation Upgrades for 241-AY and 241-AZ Tank Farms," Enclosure to DOE-RL letter ( $\mathrm{J}$. Rasmussen), number 98-EAP273, to WDOH (A. Conklin) and EPA (J. Leitch), dated May 15, 1998

Approva1: WDOH letter (A. Conklin), number AIR-98-708, to DOE-RL (J. Rasmussen), dated July 10, 1998

Approva1: EPA letter (A. Frankel) to DOE-RL (J. Rasmussen), dated July 28, 1998

j. 241-C-103 - Enhanced Ventilation System (No WDOH NOC Required)

"Notice of Construction for the Enhanced Ventilation of Tank 241-C-103 to Mitigate Noxious and Hazardous Vapors," Enclosure to DOE-RL letter (J. Rasmussen), number 95-PRI063, to Ecology (J. Stohr), dated June 23, 1995

Approval: Ecology letter (J. Stohr) to DOE-RL (J. Rasmussen), dated June 28, 1995

"Request for Approval to Use an Alternative Method for Sampling and Analysis of Non-Methane Organic Compounds from Tank 241-C-103," Enclosure to DOE-RL letter (J. Rasmussen), number 95-TOP-217, to Ecology (R. King), dated November 27, 1995

Approval: Ecology letter (R. King) to DOE-RL ( $\mathrm{J}$. Rasmussen), dated January 26, 1996 
HNF-4474, Rev. 2

\section{k. 241-C-103 - Organic Removal (Expired/Project Dropped)}

"Radioactive Air Emissions Notice of Construction for Organic Removal from Tank 24l-C-103," Enclosure to DOE-RL letter ( $\mathrm{J}$. Rasmussen), number 94-PCA-002, to WDOH (A. Conklin) and EPA (J. McCormick), dated August 8, 1994

Approva1: WDOH letter (A. Conklin), number AIR-94-910, to DOE-RL (J. Rasmussen), dated September 8, 1994

Approval: EPA letter (J. McCormick) to DOE-RL (J. Rasmussen), dated August 31, 1994

\section{241-C-106 Sluicing - Project W-320 - Phase I (Expired)}

"National Emission Standards for Hazardous Air Pollutants Project $W-320$, Tank 241-C-106 Sluicing," Enclosure to DOE-RL letter (J. Bauer), number 94-RPS-126, to Ecology (J. Stohr), dated February 17, 1994

Approva 1: DSI from S. Stites (DOE-RL) to L. Erickson (DOE$\mathrm{RL}$ ) dated May 10, 1994. The DSI documents an Apri] 12, 1994 telecon between DOE-RL with Ecology and documents Ecology's verbal concurrence.

"National Emission Standards for Hazardous Air Pollutants Project W-320, Tank 241-C-106 Sluicing," Enclosure to DOE-RL letter (J. Bauer), number 94-RPS-124, to WDOH (A. Conk1 in), dated February 15, 1994

Approva 1: WDOH letter (A. Conklin), number AIR-94-214, to DOE-RL (J. Bauer), dated February 28, 1994

"Application for Approval for Construction Pursuant to 40 Code of Federal Regulations 61 Project $W-320$, Tank 241-C-106 Sluicing," Enclosure to DOE-RL (J. Bauer), number 94-RPS125, to EPA (J. McCormick), dated February 17, 1994

Approva 1: EPA letter (J. McCormick) to DOE-RL (J. Bauer), dated February 23, 1994 
HNF-4474, Rev. 2

m. 241-C-106 Sluicing - Project W-320 - Phase II - NonRadioactive

"Nonradioactive Air Emissions Notice of Construction Project W-320, 241-C-106 Tank Sluicing," D0E/RL-95-62, Rev. 1, Enclosure to DOE-RL ( $\mathrm{J}$. Rasmussen), number 97-EAP-114, to Ecology (J. Stohr), dated December 11, 1996

Approval: Ecology letter (M. Wilson) to DOE-RL ( $\mathrm{J}$. Rasmussen), dated October 24, 1997

"State of Washington Department of Ecology (Ecology) Approval of $W-320$ Total Organic Testing," Enclosure to DOE$\mathrm{RL}$ (J. Rasmussen), number 98-EAP-503, to Ecology (M. Wilson), dated September 11, 1998

Approval: Ecology letter (M. Wilson) to DOE-RL ( $J$. Rasmussen), dated September 23, 1998

"Revision to 241-C-106 Notice of Construction Application for Project $W-320,241-C-106$ Tank Sluicing, "Enclosure to DOE-RL (J. Rasmussen), number 99-EAP-247, to Ecology (M. Wi1son), dated April 7, 1999

Approval: Ecology letter (M. Wilson) to DOE-RL (J. Rasmussen), dated Apri1 9, 1999

n. 241-C-106 - Sluicing - Project W-320 - Phase II Radioactive

"Radioactive Air Emissions, Notice of Construction, Project W-320, Tank 241-C-106," D0E/RL-95-45, Rev. 1, dated September 1996, Enclosure to DOE-RL letter (J. Rasmussen), number 96-EAP-291, to WDOH (A. Conklin) and EPA (J. Leitch), dated September 25, 1996

Approval: WDOH letter (A. Conklin), number AIR-95-712, to DOE-RL (J. Rasmussen), dated July 31, 1995

Approval: EPA letter (J. McCormick) to DOE-RL (J. Bauer), dated February 23, 1994

Notification of Start-Up: DOE-RL letter ( $J$. Rasmussen) number 96-MSD-182, to EPA (A. Franke1), dated September 26, 1996 
"Radioactive Air Emissions Notice of Construction (NOC) Project W-320, Tank 241-C-106 Sluicing," DOE/RL-95-45, Rev. 2, Enclosure to DOE-RL letter (J. Rasmussen), number 98-EAP469, to WDOH (A. Conklin) and EPA (J. Leitch), dated August 28, 1998

Approval: WDOH letter (A. Conk1 in), number AIR-98-1002, to DOE-RL (J. Rasmussen), dated October 2, 1998

Approval: EPA letter (A. Frankel) to DOE-RL (J. Rasmussen), dated September 10, 1998

NOC Modified by Hanford Facility NOC Revision Form, April 8, 1999, DOE/RL-95-45 Rev. 2

Approval: WDOH (R. Acselrod) NOC Revision Form dated, Apri1 8, 1999

o. 241-S Ventilation System (Work Completed 1996 Per D. Scott, Only Exhauster Remains)

"Notice of Construction for the Modification of the 241-S Tank Farm Ventilation System," August 1995, Enclosure to DOE-RL letter ( $\mathrm{J}$. Rasmussen), number 95-PCA-500, to WDOH (A. Conk1in) \& EPA (P. Millam), dated September 1, 1995

Approva1: WDOH letter (A. Conk1 in), number AIR-95-1004, to DOE-RL (J. Rasmussen), dated October 12, 1995

Approva1: EPA letter (M. Busse1), to DOE-RL ( $J$. Rasmussen), dated September 20, 1995

p. 241-SY-101 - Crust Growth Near Term Mitigation (Short Form)

"Radioactive Air Emissions Notice of Construction, 241-SY101 Crust Growth Near Term Mitigation Short Form, " DOE-RL99-30, Apri1 1999

Approval: WDOH Approval Sheet (A. Conklin), dated April 23, 1999

"Radioactive Air Emissions Notice of Construction (NOC) for 241-SY-101 Crust Growth Near Term Mitigation Short Form," Enclosure to DOE-RL letter (J. Rasmussen), number 99-EAP278, to EPA (J. Leitch), dated April 29, 1999

Approval: EPA letter (A. Frankel), to DOE-RL (J. Rasmussen), dated Apri1 29, 1999 
HNF-4474, Rev. 2

"Determination of New Source Review (WAC 173-400 and 460)

Proposed SY-101 Crust Mitigation Activity," Enclosure to

LMHC letter (E. Mayer), number LMHC-9952430, to FDH (W.

Adair), dated Apri1 14, 1999

Approval: Ecology Approval Not Required

q. 241-SY-101 - Mixer Pump Replacement

"Replacement of Mixer Pump in Tank 241-SY-101," Enclosure to DOE-RL letter (J. Rasmussen), number 95-PCA-149, to WDOH (A. Conklin) and EPA (J. McCormick), dated February 1, 1995

Approval: WDOH letter (A. Conklin), number AIR-95-203, to DOE-RL (J. Rasmussen), dated February 21, 1995

Approval: EPA 1etter (J. McCormick) to DOE-RL (J. Rasmussen), dated February 14, 1995

r. 241-SY-102 - Initial Tank Retrieval Systems - Project W-211 (Expired)

"Radioactive Air Emissions Notice of Construction, Project W-211, Initial Tank Retrieval Systems," DOE/RL-95-104, January 1996, Enclosure to DOE-RL Tetter (J. Rasmussen), number 96-RTI-021, to WDOH (A. Conklin) and EPA (J. Leitch), dated February 9, 1996

Approval: EPA letter (A. Frankel.) to DOE-RL (J. Rasmussen), dated March 15, 1996

"Response to the State of Washington Department of Health's Request for More Information Concerning the Radioactive Air Emissions Notice of Construction (NOC) for Project $W-211$, Initial Tank Retrieval Systems for 241-SY-102 Tank," DOE-RL letter ( $\mathrm{J}$. Rasmussen), number 96-MSD-103, to WDOH (A. Conklin), dated July 23, 1996

Approval: WDOH letter (A. Conkl in), number AIR-96-801, to DOE-RL (J. Rasmussen), dated August 5, 1996

Clarification: WDOH letter (A. Conk1 in), number AIR-96902, to DOE-RL (J. Rasmussen), dated September 11, 1996

s. 241-UX-154 Diversion Box (Short Form)

"Notice of Construction Work in Tank Farm 241-UX-154 Diversion Box," DOE/RL-99-52, dated August 1999 
HNF-4474, Rev. 2

t. 244-A Lift Station and 241-ER-152 Diversion Box (Short Form)

"Notice of Construction Work in Tank Farm Waste Transfer Pits Designated 241-ER-152 and 244-A Lift Station," dated January 29, 1999

Approval: WDOH letter (A. Conk7 in), number AIR-99-204, to DOE-RL (J. Rasmussen), dated February 12, 1999

"Notice of Construction Work in Tank Farm Waste Transfer Pits Designated 241-ER-152 and 244-A Lift Station Short Form" Enclosure to DOE-RL letter (J. Rasmussen), number 99EAP-170, to EPA (J. Leitch), dated February 12, 1999

Approval: EPA letter (A. Franke1), to DOE-RL (J. Rasmussen), dated February 17, 1999

Notification of Start-Up: DOE-RL letter (J. Rasmussen), number 99-EAP-195, to EPA (J. Leitch), dated March 3, 1999

\section{u. 244-AR Vault}

"Radioactive Air Emissions Notice of Construction Use of a Portable Exhauster at 244-AR Vault," DOE/RL-97-05, Rev. 2, Enclosure to DOE-RL letter (J. Rasmussen), number 97-EAP618, to WDOH (A. Conklin), dated August 18, 1997

Approval: WDOH letter (A. Conk1 in), number AIR-97-1007, to DOE-RL (J. Rasmussen), dated October 9, 1997

"Radioactive Air Emissions Notice of Construction Use of a Portable Exhauster at 244-AR Vault," DOE/RL-97-05, Rev. 2, Enclosure to DOE-RL letter (J. Rasmussen) number 97-EAP-619, to EPA (J. Leitch), dated August 18, 1997

Approval: EPA Letter (A. Franke1) to DOE-RL (J. Rasmussen), dated October 24, 1997

244-AR Vault NOC Modified by Hanford Facility NOC Revision Form, February 17, 1999

Approval: WDOH (A Conklin) NOC Revision Form dated, February 17, 1999 
HNF-4474, Rev. 2

v. 244-AR Vessel Vent System (Isolation of 296-A-12 Exhauster) (Short Form)

"Radioactive Air Emissions Notice of Construction for Isolation of 296-A-12 Exhauster from the 244-AR Vessel Vent System, " DOE/RL-99-55, Rev. 0, dated August 1999

Approval: WDOH Approval Sheet (A. Conklin), dated August 9, 1999

"Isolation of 296-A-12 Exhauster from the 244-AR Vessel Vent System," Telephone Conference Memorandum, between WMH \& EPA, dated August 11, 1999

Approval: Per Telephone Conference Memorandum, EPA Approval is not required

w. 244-TX Double Contained Receiver Tank (Short Form)

"Notice of Construction Work in Tank Farm Waste Transfer Pit 244-TX Double-Contained Receiver Tank," July 1999, DOE/RL99-47. Enclosure to DOE-RL letter (J. Rasmussen), number 99EAP-402, to EPA (J. Leitch), dated July 28, 1999

Approva1: WDOH letter (A. Conkl in), number AIR-99-805, to DOE-RL (J. Rasmussen), dated August 30, 1999

\section{x. 244-U Double Contained Receiver Tank (Expired)}

"Radioactive Air Emissions Notice of Construction 244-U Double Contained Receiver Tank, "Enclosure to DOE-RL letter (J. Rasmussen), number 94-PCA-034, to WDOH (A. Conklin) and EPA (J. McCormick), dated September 16, 1994

Approval: WDOH letter (A. Conk7 in), number AIR-94-919, to DOE-RL (J. Rasmussen), dated October 4, 1994

Approval: EPA letter (J. McCormick) to DOE-RL (J. Rasmussen), dated October 6, 1994

"Revision to the Radioactive Air Emissions Notice of Construction for the 244-U Double Contained Receiver Tank," Enclosure to DOE-RL letter (J. Rasmussen), number 97-EAP045, to WDOH (A. Conk1 in), dated October 30, 1996

Approval: WDOH letter (A. Conk1 in), number AIR-96-1110, to DOE-RL (J. Rasmussen), dated November 26, 1996 
HNF-4474, Rev. 2

"Revision to the Radioactive Air Emissions Notice of Construction for the 244-U Double Contained Receiver Tank," Enclosure to DOE-RL letter (J. Rasmussen), number 97-EAP046, to EPA (J. Leitch), dated October 30, 1996

y. 244-U Double Contained Receiver Tank BY-Pass (Short Form)

"Notice of Construction By-Passing the 244-U Double Contained Receiver Tank During Salt Well Pumping"

Approval: WDOH Approval Sheet (A. Conk1 in), dated May 4, 1999

"Notice of Construction By-Passing the 244-U Double Contained Receiver Tank During Salt Well Pumping (Short Form)," Enclosure to DOE-RL letter (J. Rasmussen), number 99-EAP-282, to EPA (J. Leitch), dated May 5, 1999

Approval: EPA letter (A. Frankel), to DOE-RL ( 3 . Rasmussen), dated May 7, 1999

"New Source Reviews Under Washington Administrative Code 173-400 and Washington Administrative Code 173-460," Enclosure to WMH letter (E. Greager), number WMH-9953153, to LMHC (D. Carre11), dated May 6, 1999

Approval: Ecology Approval Not Required

z. Isolation of 296-P-17 Exhauster from the 241-A-105 Tank (Short Form)

"Radioactive Air Emissions Notice of Construction for Isolation of 296-P-17 Exhauster from the 241-A-105 Tank

Approval: WDOH Approval Sheet (A. Conkl in), dated September 15, 1999

aa. Categorical Use of the Guzzler Vacuum Excavation System (Short Form)

"Categorical Notice of Construction for Use of the Guzzler Vacuum Excavation System for Radiologically Limited Activities on the Hanford Site."

Approval: WDOH letter (A. Conk1 in), number AIR-98-1215, to DOE-RL (J. Rasmussen), dated December 18, 1998 
"National Emissions Standard for Hazardous Air Pollutants Application for Approval of the Categorical Use of the Guzzler Vacuum Excavation System for Radiologically Limited Activities on the Hanford Site, "Enclosure to DOE-RL Tetter (J. Rasmussen), number 99-SID-021, to EPA (J. Leitch), dated February 1, 1999

Approval: EPA letter (A. Franke1), to DOE-RL (J. Rasmussen), dated March 11, 1999

ab. Cone Penetrometer, 241-AX-104 (Short Form)

"Soil Characterization Around 241-AX-104 Tank Using the Cone Penetrometer (Short Form), "Enclosure to DOE-RL letter (J. Rasmussen), number 98-EAP-576, to WDOH (A. Conk 7 in), dated October 15, 1998

Approval: WDOH letter (A. ConkTin), number AIR-98-1009, to DOE-RL (J. Rasmussen), dated October 29, 1998

"Soil Characterization Around 241-AX-104 Tank Using the Cone Penetrometer," Enclosure to DOE-RL letter (J. Rasmussen), number 99-EAP-005, to EPA (J. Leitch), dated October 26, 1998 (No Approval from EPA Needed)

ac. Cross-Site Transfer System - Project W-058 (Short Form) (Completed)

"Radioactive Air Emissions Short Form Notice of Construction (NOC) for Project W-058 Excavation and Backfilling in Support of the Cross-Site Transfer System," Enclosure to DOE-RL letter (J. Rasmussen), number 97-EAP-449, to WDOH (A. Conk7 in), dated June 9, 1997.

Approval: WDOH Approval Sheet (A. Conk7in), dated June 13, 1997

"Radioactive Air Emissions Short Form Notice of Construction (NOC) for Project W-058 Excavation and Backfilling in Support of the Cross-Site Transfer System," Enclosure to DOE-RL letter (J. Rasmussen), number 97-EAP-448, to EPA (J. Leitch), dated June 9, 1997.

Approval: EPA Tetter (A. Frankel) to DOE-RL (J. Rasmussen), dated June 19, 1997 
HNF-4474, Rev. 2

ad. Decommissioning and Sampling of Borehole 41-09-39 (Short Form)

"Notice of Construction for Tank Waste Remediation System Decommissioning and Sampling of Borehole 4l-09-39 (Short Form)"

Approva 1: WDOH Approval Sheet (A. Conk1 in), dated May 7, 1999

"Radioactive Air Emissions Notice of Construction for the Tank Waste Remediation System Decommissioning and Sampling of Borehole 41-09-39," Enclosure to DOE-RL letter ( $J$.

Rasmussen), number 99-EAP-296, to EPA (J. Leitch), dated May 10,1999

Approval: EPA letter (A. Frankel) to DOE-RL (J. Rasmussen), dated May 20, 1999

"New Source Reviews Under Washington Administrative Code 173-400 and Washington Administrative Code 173-460,"

Enclosure to WMH letter (E. Greager), number WMH-9953153, to LMHC (D. Carre11), dated May 6, 1999

Approval: Ecology Approval Not Required

ae. Portable Exhauster/Saltwell Pumping - Non-Radioactive

"Nonradioactive Air Emissions Notice of Construction Use of Portable Exhauster on Single-Shell Tanks During Saltwell Pumping, "DOE/RL-97-10, July 1998, Enclosure to DOE-RL letter (J. Rasmussen), number 98-EAP-414, to Ecology (M. Wilson), dated August 12, 1998

Approval: Ecology letter (M. Wilson) to DOE-RL (J. Rasmussen), dated October 23, 1998

"Addition of Tanks 241-T-104 and 241-T-110 to the NonRadioactive Air Emissions Notice of Construction Use of a Portable Exhauster on Single-Shell Tanks During Salt Well Pumping," Enclosure to DOE-RL letter (J. Rasmussen), number 99-EAP-378, to Ecology (M. Wilson), dated June 30, 1999

Approva1: Ecology letter (M. Wilson) to DOE-RL (J. Rasmussen), dated Ju7y 7, 1999 
HNF-4474, Rev. 2

"Addition of Tank 241-A-101 to the Non-Radioactive Air Emissions Approval Order Number DE98NWP-006, Use of a Portable Exhauster on Single-Shell Tanks During Salt-Wel1 Pumping, "Enclosure to DOE-RL letter (J. Rasmussen), number 99-EAP-469, to Ecology (M. Wilson), dated August 26, 1999

Approval: Ecology letter (M. Wilson) to DOE-RL (J. Rasmussen), dated September 23, 1999

af. Portable Exhauster/Saltwell Pumping - Radioactive

"Radioactive Air Emissions Notice of Construction Use of a Portable Exhauster on Single-Shell Tanks During Saltwell Pumping," DOE/RL-97-09, Rev. 2, August 1998, Enclosure to DOE-RL letter (J. Rasmussen), number 98-EAP-491, to WDOH (A. Conklin) \& EPA (J. Leitch), dated September 8, 1998

Approva1: WDOH letter (A. ConkT in), number AIR-98-1207, to DOE-RL (J. Rasmussen), dated December 16, 1998

Approva1: EPA letter (A. Franke1) to DOE-RL (J. Rasmussen), dated October 15, 1998

NOC Modified by Hanford Facility NOC Revision Form, June 17, 1999, DOE/RL-97-09 Rev. 3

Approva1: WDOH (R. Acselrod) NOC Revision Form dated, June 17,1999

Approval: EPA letter (A. Frankel) to DOE-RL (J. Rasmussen), dated August 10, 1999

NOC Modified by Hanford Facility NOC Revision Form, July 31, 1999, D0E/RL-97-09 Rev. 4

Approval: WDOH (R. Acselrod) NOC Revision Form dated, July 31,1999

ag. Portable Temporary Radioactive Airborne Emissions Units

"Annual update, DOE/RL-96-75, Rev. 1, State of Washington, Department of Health, Radioactive Air Emissions Notice of Construction Portable/Temporary Radioactive Air Emissions Units," DOE/RL-96-75, Rev. 1, dated August 1997, Enclosure to DOE-RL letter (J. Rasmussen), number 97-EAP-651, to WDOH (A. Conklin), dated September 16, 1997

Approval: WDOH letter (A. Conkl in), number AIR-97-1207, to DOE-RL (J. Rasmussen), dated December 15, 1997 
"Annual update, DOE/RL-96-75, Rev. IA, State of Washington Department of Health, Radioactive air Emissions Notice of Construction Portable/Temporary Radioactive Air Emissions Units," DOE/RL-96-75, Rev. 1A, dated August 1998, Enclosure to DOE-RL letter ( $\mathrm{J}$. Rasmussen), number 98-EAP-478, to WDOH (A. Conklin), dated September 1, 1998

Approva 1: WDOH letter (A. Conklin), number AIR 98-1008, to DOE-RL (J. Rasmussen), dated October 22, 1998

"Radioactive Air Emissions Notice of Construction Portable/Temporary Radioactive Air Emission Units, "DOE/RL96-75, Rev. 2, dated June 1999, Enclosure to DOE-RL letter (J. Rasmussen), number 99-EAP-383, to WDOH (A. Conklin), dated June 30, 1999

ah. Radioactive Air Emissions Notice of Construction Project W314 - Tank Farms (Short Form)

"Radioactive Air Emissions Notice of Construction Project $W$ 314 Tank Farm Restoration and Safe Operations, "Enclosure to DOE-RL letter (J. Rasmussen), number 97-EAP-760, to WDOH (A. ConkTin), dated December 8, 1997

Approva 1: WDOH letter (A. Conk1 in), number AIR-98-302, to DOE-RL (J. Rasmussen), dated March 5, 1998

"Radioactive Air Emissions Notice of Construction Project W314 Tank Farm Restoration and Safe Operations (Short Form)," Enclosure to DOE-RL letter ( 3 . Rasmussen), number 97-EAP761, to EPA (J. Leitch), dated December 8, 1997

Approva1: EPA letter (A. Franke1) to DOE-RL ( $J$. Rasmussen), dated December 23, 1997

"Notice of Construction Tank Farm Restoration and Safe Operations Project $W-314$ (Short Form), Revision 1," dated March 23, 1999

Approva 1: WDOH letter (A. Conk1 in), number AIR-99-404, to DOE-RL (J. Rasmussen), dated Apri1 19, 1999

"Notification of New Source Review Exemption for Project W314 Under Washington Administrative Code (WAC) 173-400," Enclosure to DOE-RL letter (J. Rasmussen), number 99-EAP212, to Ecology (M. Wilson), dated March 22, 1999

Approval: Ecology Approval Not Required 
HNF-4474, Rev. 2

ai. Radioactive Air Emissions Notices of Construction for Project W-420, Stack Monitoring System Upgrades for the 296A-25, 296-B-28, 296-C-05, 296-P-16, 296-S-22, and 296-T-18 Stacks (Short Forms)

"Radioactive Air Emissions Notices of Construction for Project $W-420$, Stack Monitoring System Upgrades for the 296$\mathrm{A}-25,296-\mathrm{B}-28,296-\mathrm{C}-05,296-\mathrm{P}-16,296-\mathrm{S}-22$, and 296-T-18 Stacks (Short Forms), "Enclosure to DOE-RL letter (J. Rasmussen), number 99-EAP-100, to WDOH (A. Conklin) \& EPA (J. Leitch), dated December 22, 1998

Approval: WDOH letter (A. Conk1in), number AIR-99-115, to DOE-RL (J. Rasmussen), dated January 29, 1999

Approval: EPA letter (A. Frankel) to DOE-RL ( $J$. Rasmussen), dated January 7, 1999

"W-420 Excavation Activities at the 296-B-28, 296-C-05, 296-P-16, 296-S-22, and 296-T-18 Stacks Resume-Work

Strategy," dated May 5, 1999

Approval: WDOH Approval Sheet (A. Conklin), dated May 6, 1999

"New Source Review Under Washington Administrative Codes 173-400 and 173-460 for Project $W-420$, Stack Monitoring System Upgrades for the 296-A-25, 296-B-28, 296-C-05, 296-P16, 296-S-22, and 296-T-18 Stacks, "Enclosure to DOE-RL letter ( 3 . Rasmussen), number 99-EAP-173, to Ecology (M. Wilson), dated March 1, 1999

Approval: Ecology Approval Not Required

aj. TWRS High-Efficiency Particulate Air (HEPA)

Filtered Vacuum Approval (Superseded by Site-Wide HEPA NOC)

"Approval Request for the U.S. Department of Energy, Richland Operations Office (RL) Tank Waste Remediation System (TWRS) Use of T-Plant Notice of Construction (NOC) for Use of Euro Vacuums Model UZ 948," Enclosure to DOE-RL letter (J. Rasmussen), number 97-EAP-499, to EPA ( $J$. Leitch), dated June 23, 1997

Approva 1: EPA letter (A. Frankel) to DOE-RL (J. Rasmussen), dated July 3, 1997

Approval: WDOH letter (A. Conklin), number AIR-97-607, to DOE-RL (J. Rasmussen), dated June 12, 1997 
ak. Site-Wide HEPA Filtered Vacuum - Radioactive

"Radioactive Air Emissions Notice of Construction HEPA Filtered Vacuum Radioactive Air Emissions Units," Enclosure to DOE-RL letter ( $J$. Rasmussen), number 97-EAP-791, to WDOH (A. Conklin), dated November 26, 1997

Approva 1: WDOH letter (A. Conklin), number AIR-98-312, to DOE-RL (J. Rasmussen), dated March 25, 1998

"Radioactive Air Emissions Notice of Construction HEPA Filtered Vacuum Radioactive Air Emissions Units," Enclosure to DOE-RL letter (J. Rasmussen), number 97-EAP-792, to EPA (A. Frankel), dated November 26, 1997

Approval: EPA letter (A. Franke1) to DOE-RL (J. Rasmussen), dated January 8, 1998

"Radioactive Air Emissions Notice of Construction for HEPA Filtered Vacuum Radioactive Air Emission Units," DOE/RL-9750, Rev. 1, dated June 1999, Enclosure to D0E-RL letter (J. Rasmussen), number 99-EAP-383, to WDOH letter (A. Conklin), dated June 30, 1999

a1. Cask Truck - LR56 (Project Dropped)

"Request for Approval of an Alternate Method for Flow measurements for the LR56 Cask Truck," Enclosure to DOE-RL letter ( $\mathrm{J}$. Rasmussen), number 97-EAP-006, to EPA ( $\mathrm{J}$. Leitch), dated October 23, 1996

(A letter was never sent to Ecology)

Approva 1: EPA letter (A. Franke) to DOE-RL ( $J$. Rasmussen), dated JuTy 17, 1997

am. Underground Storage Tanks \& Ancillary Piping (Completed)

"Notice of Construction for Excavation and Backfill Activity for Two Diesel Underground Storage Tanks and Ancillary Piping"

Approval: WDOH Signature (A. Conklin), dated August 18, 1998 


\section{an. Vadose Zone Characterization}

"Notice of Construction for Tank Waste Remediation System Vadose Zone Characterization," DOE/RL-99-34, dated May 1999, Enclosure to DOE-RL letter (J. Rasmussen), number 99-EAP328 , to WDOH (A. Conklin) \& EPA (J. Leitch), dated June 3 , 1999

Approval: WDOH letter (A. Conklin), number AIR-99-701, to DOE-RL (J. Rasmussen), dated July 14, 1999

Approva1: EPA letter (A. Frankel) to DOE-RL (J. Rasmussen), dated June 14, 1999

"Notification of New Source Review Exemption for 241-SX Vadose Zone Project Under Washington Administrative Code 173-400 and 173-460," Enclosure to DOE-RL (J. Rasmussen), number 99-EAP-313, to Ecology (M. Wilson), dated May 18, 1999

Approval: Ecology Approval Not Required

Tank Waste Remediation System Vadose Zone Characterization NOC Modified by Hanford Facility NOC Revision Form, August 16,1999

Approval: WDOH (A Conklin) NOC Revision Form dated, August 23, 1999 
HNF-4474, Rev. 2

D. Notices of Construction and Approvals. Characterization Program

a. Rotary Mode Core Sampling Truck - Two - Non-Radioactive (Expired)

"NESHAPS Application for Approval to Construct Rotary Mode Core-Sampling Truck and Exhauster," DOE/RL-93-39, dated May 1993, Enclosure to DOE-RL letter (J. Rasmussen), number 93RPS-245, to EPA (J. McCormick), dated June 25, 1993

Approval: EPA letter (J. McCormick) to DOE-RL (R. Holt), dated August 9, 1993

"Radioactive Air Emissions Program Notice of Construction, Rotary Mode Core Sampling Truck and Exhauster, "DOE/RL-9340, dated May 1993, Enclosure to DOE-RL letter (J.

Rasmussen), number 93-RPS-244, to WDOH (A. Conk 7 in), dated June 25, 1993

Approva1: WDOH letter AIR-93-707 (A. Conk1 in) to DOE-RL (J. Rasmussen), dated July 8, 1993

Approva 1: Ecology letter (D. Jansen) to DOE-RL (J. Bauer), dated November 22, 1993

"Modification of Total Carbon and Ammonia Monitoring Requirements for the Rotary Mode Core Sampling System," Enclosure to DOE-RL letter (J. Rasmussen), number 95-PCA291, to Ecology (J. Stohr), dated May 2, 1995

Approval: Ecology letter (J. Stohr) to DOE-RL (J. Rasmussen), dated May 11, 1995

b. Rotary Mode Core - Sampling Three, Four and Modification to Two - Non-Radioactive

"Toxic Air Pollutants Notice of Construction for Rotary Mode Core-Sampling Systems Three and Four and Modifications of System Two," DOE/RL-94-117, May 1995, Enclosure to DOE-RL letter ( $\mathrm{J}$. Rasmussen), number 95-PCA-351, to Ecology ( $\mathrm{J}$. Stohr), dated June 9, 1995

Approval: Ecology letter (J. Stohr) to DOE-RL (J. Rasmussen), dated June 30, 1995

"Modification of the Rotary Mode Core Sampling Air Permit," Ecology letter (R. King) to DOE-RL (J. Rasmussen) 
DOE-RL Response: "Response to State of Washington Department of Ecology (Ecology) for the Modification of the Rotary Mode Core Sampling (RMCS) Air Permit, "DOE-RL letter (J. Rasmussen), number 96-WSD-111, to Ecology (M. Wilson), dated June 26, 1996

Notification of Start-Up: Ecology CC:Mail Message ( $J$. Hensley) to Distribution, dated Apri1 30, 1998

"Toxic Air Pollutants Notice of Construction for Rotary Mode Core-Sampling Systems Three and Four and Modification of System Two," DOE/RL-94-117, Rev. 1, dated July 1998, Enclosure to D0E-RL 1etter (J. Rasmussen), number 98-EAP345, to Ecology (M. Wilson), dated July 15, 1998

Approva1: Ecology letter (M. Wilson) to DOE-RL (J. Rasmussen), dated September 3, 1998

c. Rotary Mode Core-Sampling Systems Three and Four Radioactive

"Radioactive Air Emissions Program Notice of Construction for the Rotary Mode Core-Sampling Systems Three and Four," DOE/RL-94-118, dated May 1995, Enclosure to DOE-RL letter (J. Rasmussen), number 95-PCA-352, to WDOH (A. Conkl in), dated June 9, 1995

Approva 1: WDOH letter (A. Conkl in), number AIR-95-603, to DOE-RL (J. Rasmussen), dated June 30, 1995

"National Emission Standard for Hazardous Air Pollutants Application for Approval to Construct Rotary Mode CoreSampling Systems Three and Four," DOE/RL-94-116, May 1995, Enclosure to DOE-RL letter (J. Rasmussen), number 95-PCA350, to EPA (P. Millam), dated June 9, 1995

Approva 1: EPA letter (P. Millam) to DOE-RL (3. Rasmussen), dated June 11, 1995

Notification of Start-Up: DOE-RL letter ( $J$. Rasmussen), number 95-PCA-448, to EPA ( $P$. Milliam), dated August 9, 1995

Notification of Start-Up: DOE-RL letter (J. Rasmussen), number 96-EPA-233, to EPA ( $\mathrm{J}$. Leitch), dated July 22, 1996 
HNF-4474, Rev. 2

Notification of Start-Up: DOE-RL letter (J. Rasmussen), number 97-EAP-136, to EPA ( $\mathrm{J}$. Leitch), dated December 20, 1996

Notification of Start-Up: DOE-RL letter (J. Rasmussen), number 97-EAP-316, to EPA ( $\mathrm{J}$. Leitch), dated March 24, 1997

"Radioactive Air Emissions Program Notice of Construction for the Rotary Mode Core-Sampling System Three and Four," D0E/RL-94-118, Rev. 1, dated July 1997, Enclosure to DOE-RL letter (J. Rasmussen), number 97-EAP-591, to WDOH (A. Conklin), dated July 29, 1997

Approva1: WDOH letter (A. Conk1 in), number AIR-97-901, to DOE-RL (J. Rasmussen), dated September 3, 1997

"Radioactive Air Emissions Program Notice of Construction for the Rotary Mode Core-Sampling System Three and Four," D0E/RL-94-118, Rev. 1, dated July 1997, Enclosure to DOE-RL letter (J. Rasmussen), number 97-EAP-590, to EPA ( $\mathrm{J}$. Leitch), dated Ju1y 29, 1997

Approva 1: EPA letter (A. Franke1) to DOE-RL (J. Rasmussen), dated August 4, 1997

"Additional Information Requested in the State of Washington Department of Health (WDOH) Rotary Mode Core Sampling (RMCS) Approval Letter," Enclosure to DOE-RL letter (J. Rasmussen), number 98-EAP-011, to WDOH (A. Conk in), dated January 22, 1998

Approva 1: WDOH letter (A. Conk1 in), number AIR-98-301, to DOE-RL (J. Rasmussen), dated March 6, 1998

\section{d. Rotary Mode Core-Sampling - 241-SX Tank Farms}

"Radioactive Air Emissions Notice of Construction for Rotary Mode Core Sampling in SX Tank Farm," DOE/RL-97-70, September 1997, Enclosure to DOE-RL letter (J. Rasmussen), number 97EAP-722, to WDOH (A. Conkl in), dated October 17, 1997

Approval: WDOH letter (A. Conk1 in), number AIR-97-1101, to DOE-RL (J. Rasmussen), dated November 13, 1997 
"Radioactive Air Emissions Notice of Construction for Rotary Mode Core Sampling in SX Tank Farm," DOE/RL-97-70, September 1997, Enclosure to DOE-RL letter (J. Rasmussen), number 97EAP-723, to EPA (J. Leitch), dated October 17, 1997

Approval: EPA letter (A. Frankel) to DOE-RL $(J$. Rasmussen), dated January 14, 1998

e. 241-SX-104 Salt Well Pumping (Short Form)

"Radioactive Air Emissions Short Form Notice of Construction for Salt We17 Pumping Tank 241-SX-104," Enclosure to DOE-RL letter (J. Rasmussen), number 98-EAP-137, to WDOH (A.

Conk1in), dated March 10, 1998

Approval: WDOH Approval Sheet (A. Conklin), dated March 12, 1998

Approval: EPA letter (A. Franke1) to DOE-RL (J. Rasmussen), dated March 19, 1998

"Salt Well Pumping Tank 241-SX-104 (New Source Review)", LMHC letter ( $E$. Mayer), number LMHC-9851777, to FDH ( $A$. Umek), dated February 27, 1998

Approva1: Ecology Approval Not Required

\section{f. 241-SX-106 Salt We11 Pumping (Short Form)}

"Radioactive Air Emissions Short Form Notice of Construction (NOC) for Saltwell Pumping of Tank 241-SX-106," Enclosure to DOE-RL letter ( $\mathrm{J}$. Rasmussen), number 98-EAP-375, to EPA ( $A$. Franke1), dated July 15, 1998

Approva 1: WDOH Approval Sheet (R. Ascelrod), dated July 2, 1998

Approval: EPA letter (A. Franke1) to DOE-RL (J. Rasmussen), dated July 21, 1998

"New Source Review of 241-SX-106 Salt-Well Pumping," LMHC Interoffice Memo (D. Carre11), number 7B210-99-002, to Letter to File, dated May 18, 1999

Approval: Ecology Approval Not Required 


\section{g. Light Duty Utility Arm}

"NESHAPS Application for Approval to Construct, for the Temporary Use of a Portable Exhauster in Conjunction with the Light Duty Utility Arm (LDUA [ETN-96-0007]) System," Enclosure to DOE-RL letter (J. Rasmussen), number 96-MSD077, to EPA (J. Leitch), dated May 2, 1996

Approval: EPA letter (A. Franke1) to DOE-RL (J. Rasmussen), dated July 2, 1996

WDOH Routine Technical Assistance Meeting, Light Duty Utility Arm System for Use in Single-She17 and Double-Shel1 Tanks with an Exhauster, ETN-96-0007, dated March 12, 1996

Approval: WOOH Routine Technical Assistance Meeting Minutes, dated March 12, 1996 
HNF-4474, Rev. 2

\section{SITE WIDE WATER PERMITS}

A. Registration of $\mathrm{Cl}$ ass $V$ Underground Injection Wells, DOE/RL-88-11, Rev. 1, dated August 1995

B. State Waste Discharge Permit Number ST 4508, Hydrotest, Maintenance, and Construction, Issuance Date, May 15, 1997, Expiration Date, May 15, 2002

C. State Waste Discharge Permit Number 4509, Cooling Water and Condensate Discharge, Issuance Date, May 1, 1998, Expiration Date, May 1, 2003

D. State Waste Discharge Permit Number 4510, Industrial Stormwater Discharges to Engineered Land Disposal Structures, Issuance Date, April 1, 1999, Expiration Date, Apri1 1, 2004

E. Onsite Sewage Systems Operating Permit, U.S. Department of Energy, Hanford Reservation, Benton Co., Permit number HAN099, permit expires on $9 / 24 / 99$, issued on $9 / 24 / 98$

III Underground Petroleum Storage Tanks

A. Registration of Hanford Site Underground Petroleum Storage Tanks (UST at 204-AR, Compliance Tag A4042, Uniform Business Identifier Number, 601319923)

IV. Dangerous Waste

A. Hanford Facility RCRA Permit

1. Dangerous Waste Portion of the Resource Conservation and Recovery Act (RCRA) Permit for the Treatment, Storage, and Disposal of Dangerous Waste. Permit Number WA7890008967, Expiration Dated September 27, 2004

2. Hazardous and Solid Waste Amendment (HSWA) issued by EPA, permit number WA7890008967, Expiration Dated September 27, 2004

3. Permit Modification Schedule, Attachment 27 to the Hanford Facility RCRA Permit

4. Hanford Facility Dangerous Waste Permit Application, General Information, DOE/RL-91-28, Rev. 4, dated May 1998 
HNF-4474, Rev. 2

B. RPP Part A RCRA Permits

1. 204-AR Waste Unloading Station (10/1/99)

2. Double-She1l Tank System (10/1/99)

3. Grout Treatment Facility (10/1/99)

4. Hanford Waste Vitrification Plant (10/1/96)

5. Immobilized High-level Waste Interim Storage Unit (6/28/99)

6. Single-Shell Tank System (10/1/99)

C. RCRA Documents

1. RPP Dangerous Waste Training P1an, HNF-SD-WM-TR-026, Rev. 11, September 1999

2. Tank Farms Building Emergency Plan, HNF-IP-0263-TF

3. Double She11 Tank System Waste Analysis P1an, HNF-SD-WM-EV053, Rev. 5, September 1998

D. Closure Work Plans

1. Single Shell Tank Work Plan, DOE/RL-89-16, Rev. 1, dated May 1996

E. Closure Plans

1. 2101-M Pond, Clean Closed, November 26, 1995

2. 216-B-3 Pond, Clean Closed, June 27, 1995

V. Compliance Agreements

A. NESHAPS Compliance Order, EPA, Docket No. 1092-01-23-112/114, February 1, 1993

B. Federal Facility Compliance Agreement for Radionuclide NESHAP, February 2, 1994 
VI. NEPA

A. Final Environmental Impact Statement for the Tank Waste Remediation System, DOE/EIS-0189, September 1996

B. Record of Decision for the Tank Waste Remediation System, Hanford Site, Richland, WA. Issued by the U.S. Department of Energy in the Federal Register, 62 FR 8693, dated February 26, 1997

C. Final Environmental Impact Statement for the Safe Interim Storage of Hanford Tank Wastes, DOE/EIS-0212, October 1995 
HNF-4474, Rev. 2

\begin{abstract}
ATTACHMENT A
RPP NOTICES OF CORRECTION, NOTICES OF VIOLATION \& OTHER REGULATORY ACTIONS
\end{abstract}


HNF-4474, Rev. 2

\section{WASHINGTON STATE DEPARTMENT OF HEALTH NOTICES OF CORRECTION \& VIOLATION}

\section{WDOH LETTER\#}

AIR-96-703

AIR-97-402

AIR-97-405

AIR-97-614

AIR-99-104 (CLOSURE LETTER)

AIR-97-704

AIR-97-703

AIR-97-606

AIR-97-1015

AIR-98-303 (CLOSURE LETTER)

AIR-97-1109

AIR-98-402

AIR-99-403

AIR-99-715 (CLOSURE LETTER)

AIR-97-1201

AIR-98-404 (CLOSURE LETTER)

AIR-98-403

AIR-98-502

AIR-98-702

AIR-98-1106

AIR-99-707 (CLOSURE LETTER)

AIR-99-913 (CLOSURE LETTER)

AIR-98-501

AIR-98-706

AIR-98-709

(NOV)

AIR-98-707

AIR-99-105 (CLOSURE LETTER)

(NOV)

AIR-98-805

AIR-98-1108 (CLOSURE LETTER)
SUBJECT :

RECORD RETRIEVAL

244-A LIFT STATION, HEPA, 241-SY, PROJECT W-058

T-PLANT AIR EMISSIONS

241-T \& 241-U TANK FARMS, AND 213-W WASTE COMPACTOR $(296-W-3)$

296-T-18 (244-TX DCRT)

296-A-42 (241-AY/AZ), 296-A-12 (244-AR VESSEL VENT SYSTEM), 327-02-V (327 BUILDING DECON STACK), 291-A-1 (PUREX), 296-S-22 (244-S DCRT), 291-2-1 (PFP)

PORTABLE/TEMPORARY RADIOACTIVE AIR EMISSION UNITS (PTRAEU)

296-A-25 (244-A LIFT STATION), 296-S-22 (244-S (DCRT) , 296-P-16 (241-C-105/106)

CLOSES ISSUES IN AIR-98-502

CLOSES ALL OTHER ISSUES

324 TRITIUM RELEASE (NOTICE OF VIOLATION)

296-A-42

241-AP TANK FARM 
HNF-4474, Rev. 2

AIR-98-1206

AIR-99-204

AIR-99-205

AIR-99-504 (CLOSURE LETTER)

AIR-98-1216

AIR-99-110

AIR-99-502 (CLOSURE LETTER)

AIR-99-301

AIR-99-901

AIR-99-508
241-ER-152 DIVERSION BOX DIDN'T MEET ALARACT

PTREAU \& HEPA VACUUM NOTICES OF CONSTRUCTION

296-T-18 (244-TX DCRT)

$296-C-5$ (244-CR VAULT)

296-A-17 \& 296-P-26 (241-AY \& 241-AZ TANK FARMS)

WDOH 10-DAY REPORTS

241-SX-105 (MARCH 1998)

296-A-42 (JUNE 1998)

DSI (JOHN W. SCHMIDT)
PRESENTATION GIVEN ON $7 / 2 / 98$

CC:MAIL NOTE

241-SY ANNULUS EXHAUSTER (JULY 1998)

CC:MAIL NOTE

PRESENTATION GIVEN ON $9 / 28 / 98$

\section{WASHINGTON STATE DEPARTMENT OF HEALTH INFORMATION REQUESTS}

AIR-98-212

AIR-99-716 (CLOSURE LETTER)

AIR-98-102

CC:MAIL NOTE (AL CONKLIN) AIR-98-903
$241-C-106(296-C-6)$

WDOH QUESTIONS

$296-P-33 \& 296-P-34$

296-S-15 DUCT REPLACEMENT (JUNE 1998)

\section{WASHINGTON STATE DEPARTMENT OF ECOLOGY NOTICES OF CORRECTION}

WDOE (ECOLOGY) LETTER

WDOE (ECOLOGY) LETTER

WDOE (ECOLOGY) LETTER
241-SY TANK FARMS (JULY 8, 1998)

24l-SX-104 TANK (NOVEMBER 16, 1998)

1998 LAND DISPOSAL RESTRICTIONS (JUNE 3, 1999) (INSPECTION CONDUCTED SEPTEMBER 29, 1998) 
HNF-4474, Rev. 2

WASHINGTON STATE DEPARTMENT OF ECOLOGY INVESTIGATIONS

$\begin{array}{ll}\text { WDOE (ECOLOGY) LETTER } & \text { 241-TANK FARMS (S, SX, B, BX, BY, T, TX } \\ & \text { SINGLE SHELL TANKS (GROUND WATER CORRECT } \\ & \text { ACTION) } \\ \text { WDOE (ECOLOGY) VISIT } & 241-B-111 \text { LEVEL DECREASE } \\ \text { WDOE (ECOLOGY) } & 241-\text { AX-152 CATCH TANK LEVEL DECREASE } \\ \text { WDOE (ECOLOGY) LETTER } & \text { CROSS-SITE TRANSFER SYSTEM } \\ \text { WDOE (ECOLOGY) LETTER } & \text { M-32 (DOUBLE SHELL TANK TRANSFER SYSTEM) } \\ & \text { ENVIRONMENTAL PROTECTION AGENCY }\end{array}$

EPA MULTI-MEDIA INSPECTION 